\title{
«ПРОСВЕЩЕННЫЙ НАБЛЮДАТЕЛЬ»: ОБЩЕСТВЕННАЯ ДЕЯТЕЛЬНОСТЬ С. П. КОЛОШИНА В УСЛОВИЯХ НАЧАЛА РОССИЙСКИХ РЕФОРМ 1860-Х ГГ.
}

\author{
Н. А. Бойко \\ (Московский гуманитарный университет)
}

\begin{abstract}
Аннотация: Актуальность темы определяется необходимостью всестороннего изучения исторического опыта российской модернизации ХІХ в. В данной статье показано, что в условиях пореформенной России в определении общественных настроений заметную роль играл журнал «Зритель общественной жизни, литературы и спорта», созданный известным в 1850 - 1860-е г2. публицистом и литератором С. П. Колошиным. Автор статьи акцентирует внимание на том, что на страницах журнала обсуждались значимые проблемы, волновавшие российское общество в эпоху «Великих реформ»: последствия отмены крепостного права, крестьянский вопрос, улучшение жизни в провинции, роль железных дорог, состояние общества, пути повышения культур-ного уровня народа.
\end{abstract}

Ключевые слова: реформирование, Россия, крестьянство, общество, журнал, издатель.

\section{AN «ENLIGHTENED OBSERVER»: SOCIAL ACTIVITY OF S.P. KOLOSHIN AND THE START OF RUSSIAN REFORMS OF THE 1860s}

\author{
N. A. Boyko \\ (Moscow University for the Humanities)
}

\begin{abstract}
At the present moment, the historical experience of the 19th century Russian modernization is of special relevance and thus deserves a comprehen-sive study. Our article shows that the magazine Zritel' obshchestvennoi zhizni, literatury i sporta (The Spectator of social life, literature and sport), created and edited by the prominent publicist and writer S.P. Koloshin, played an important role in determining the public attitudes during the 1850s-1860s. We make a special focus on the fact that the magazine discussed the urgent issues of Russia's social life in the era of the "Great Reforms", such as the consequences of the abolition of serfdom, the peasant 'question', the improvement of living standards in the provinces, the role of the railways, the state of society, and the ways to improve the people's level of culture.
\end{abstract}

Keywords: reform, 19th century Russia, peasantry, society, magazine, publisher.

В условиях начавшихся в 1860-е годы реформ в России русские литераторы выполняли широкие социальные функции своего рода «совести нации», «властителей дум», олицетворяя собой общественную трибуну в жизни страны. Посредством общественной и просветительской (литературной, публицистической, издательской, политической и др.) деятельности они оказали влияние на формирование общественного сознания пореформенной России. 
Одним из них был Сергей Павлович Колошин (1822-1869). Однако имя этого российского публициста, литератора, издателя, общественного деятеля, широко известное в 1850-1860-х гг. не только в России, но и в Европе, сегодня знакомо немногим. В словарях и энциклопедиях о нем написано кратко, причем скудные биографические данные содержат недочеты.

19 февраля 1861 г. произошло великое историческое событие - отмена крепостного права. В этом же году осуществилось самое важное событие в творчестве Колошина, осуществление его мечты - началось издание собственного журнала. Первый номер колошинского журнала «Зритель общественной жизни, литературы и спорта» вышел 16 декабря 1861 г.

Изучение исторических аспектов изучаемой темы возможно с учетом современных методологических тенденций развития исторической науки, направленных на репрезентацию исторической реальности (включая объяснение, интерпретацию, поиск смысла, понимание), на основе перспективных направлений исторического знания - истории повседневности, интеллектуальной истории, новой социокультурной и культурно-социальной истории, имагологии и др. (см.: Бойко, 2014; Васильев, 2006, 2009ab, 2011; Жукова Л., Жукова О., 2014; Туманов, 2010).

После отмены крепостного права изменение социального и общественного положения крепостных коснулось не только самих крестьян, но и дворянства, купцов, мещанства, происходила ломка духовного сознания у всех слоев общества. В журнале Колошина нашли отражение все самые волнующие общество темы, в нем четко прослеживается позиция редактора на многие животрепещущие вопросы того времени. Сам выбор рубрик указывал на интересы редактора и направление журнала. Интересно оформление обложки издания - картинка тоже имела смысл. На ней друг Колошина К. Рихау сделал изображение Колошина, так его описывали современники: «Брюнет среднего роста, носил усы и пиджак» (Российский государственный архив литературы и искусства - РГАЛИ. Ф. 191. ОП. 1. Д. 3385. Л. 50-51). На картинке редактор журнала сидел за своим письменным столом, повернувшись спиной к городской уличной жизни, а рядом стояла подзорная труба; он посмотрел, что делалось в городе через трубу, после чего принимался описывать то, что увидел, в этом положении он и изображен. Подобное изображение отражало реальность: С. П. Колошин называл себя просвещенным наблюдателем, зрителем в жизни города и страны, поэтому журнал так и назывался - «Зритель общественной жизни, литературы и спорта».

Выражая дух времени реформ, Колошин, представитель дворянского рода, утверждал, что пора дворянам и всем слоям общества привыкнуть обращаться с бывшими крепостными на равных, так как они получили такие же права, как и все население. Он писал, что нужно заботиться об 
уничтожении наследственных различий, завещанных «ошибками отцов», стараться узнавать друг друга, и при этом изучать наше отечество со всех сторон как почву, от разработки которой зависит общее будущее. Возврата к крепостному праву не произойдет, как все еще надеялись некоторые, поэтому надо менять свое отношение к бедным, если мы действительно хотим быть просвещенным обществом.

Журнал «Зритель общественной жизни, литературы и спорта» выходил еженедельно по субботам. Он содержал публицистические статьи на острые социальные темы, а также художественные произведения как русских писателей, так и зарубежных, которые Колошин переводил сам.

С лета 1862 г., через полгода после выпуска первого номера «Зрителя» картинка на обложке изменилась: теперь Колошин повернулся лицом к городу, он сидел на пригорке и наблюдал через подзорную трубу за городской жизнью. Если в 1861 - начале 1862 г. Колошин писал в основном о культурной жизни, то во второй половине 1862 г. его внимание переключилось на состояние общества в этот период. Перемены в обществе, в том числе и изменения в духовном сознании людей, происходили во всем обществе, и это касалось не только Москвы. Колошин много путешествовал по России и видел, как менялась жизнь людей, о своих впечатлениях он писал на страницах «Зрителя». Пожалуй, все самые основные вопросы, которые волновали общество в этот период, были отражены в журнале.

Однако Колошин сетовал на то, что у него было мало провинциальных новостей, он призывал читателей и писателей из провинции присылать сообщения, делиться опытом, представлять описания сельского и городского быта, писать о событиях в городах и губерниях, о местных нуждах. С самого первого номера «Зрителя» Колошин приглашал помещиков из великороссийских губерний сообщать о хозяйственных нововведениях, которые «были или будут удачно приложены к новому порядку отношений между землевладельцем и крестьянином» (Колошин, 1861b: 40). Он утверждал, что столичные жители не равнодушны к жизни провинции, напротив, столица желала знать о ее жизни, но провинция не давала информации о себе. Колошин писал: неважно, если корреспондент не будет обладать литературными навыками, важны только события, а литературная грамотность будет подправлена.

Колошин не оставлял этот вопрос без внимания. Он сам путешествовал по России и делился впечатлениями о провинции на страницах «Зрителя». Он осуждал многих ученых людей, которые писали о русской жизни, не выходя из кабинетов, не общаясь с этими людьми. Поэтому, несмотря на загруженность редакторской работой, Колошин находил время для своих путешествий, потому что считал: чтобы писать о чем-то, надо это увидеть своими глазами. Он любил разговаривать с прислугой, 
крестьянами, потому что только так можно было узнать, какие проблемы волнуют простых людей, увидеть и понять этих людей. По этой причине в номерах появлялись статьи о русских городах.

Первое путешествие Колошина во время редакторской работы в «Зрителе» было в Саратов в январе 1862 года. Он был приглашен правлением московско-саратовской железной дороги проехаться по первому пробному маршруту. О том, что железные дороги важны для России, не сомневался никто, уверял Колошин. Если дорога из Петербурга в Москву была построена для правительства, петербургско-варшавская - по стратегическим соображениям, то московско-нижегородская линия была торговой, важность которой была неоспоримой. По мнению Колошина, все железные дороги нужны, но не все необходимы. В этом смысле дорога из Москвы в Саратов являлась необходимостью. Главное материальное богатство России - это земля, почва, а Саратов как раз принадлежит к плодороднейшим краям и благоприятнейшим для скотоводства, и кажется, для всех ясна польза от сближения этой части с центром. После уничтожения подневольного земледельческого труда и помещику, и мужику более чем когда-нибудь нужна помощь для облегчения земледелия: требуется сельскохо-зяйственная техника и содействие в сбыте своей продукции, и тогда все остались бы в выгоде. Казалось бы, это ясно всем, но не так все было на практике, писал Колошин. Купцы, которые сбывали продукцию в Мо-скве, все равно ставили высокую цену. Русские купцы равнодушны к железной дороге и вообще к улучшению положения всего народа, они заинтересованы только в своей выгоде. «Ни один кабак так не рассчитывает на бездорожье, ни один кабак так не радуется распутице, как русский хлебный торговец; прибавлю ни один кабак никогда так не блаженствовал от горя и нужды народной, как блаженствовал, и частью продолжает блаженствовать русский хлебный торговец», - писал Колошин (Колошин, 1861a: 199). Поэтому купцам невыгодны ни хорошие дороги, ни сообщения с другими городами. К тому же многие помещики и крестьяне зависели еще от купцов. Поэтому выгоду для земледельцев Колошин видел в том, что они могли сами, без посредничества купцов, по железной дороге доставлять свой товар в Москву, и Москве товар бы доставался дешевле. Но Колошин рассказал случай, как один крестьянин поехал торговать в Москву, и вернулся оттуда без денег, просидел в тюрьме четыре месяца, потому что его приметы не совпадали с паспортными данными. Конечно, замечал Колошин, случай не ежедневный, но власти могли бы облегчить паспортную волокиту и создать более выгодные условия для продажи сельскохозяйственной продукции в Москве.

Колошин отмечал, что доверия к железной дороге у населения пока не было. В Америке, сообщал он, если в степь протянуть дорогу, то через 
10 лет там будет город, но Америка и Россия по характеру народа противоположны: американец деятелен, а у нас как ни хвали русского, он начнет дело, да и быстро бросит, а вообще русский всегда хотел все даром получить - так рассуждал Колошин. Но это невежество пройдет, надо только подождать, и все со временем убедятся в пользе новых дорог. Своими статьями Колошин пытался победить это невежество, потому что о постройке новых дорог он сообщал регулярно, доказывал их пользу. Он был уверен, что одного сообщения недостаточно для читателя, сообщения надо всегда объяснять. Например, Колошин сообщил о торжественном открытии саратовско-коломенского участка железной дороги, а некоторые газеты его «открыли» уже неделю назад, потому что тогда ее опробовали офи-циальные лица. Для нашей печати, возмущался Колошин, главное - заявить о «факте прогресса», а был ли факт и какое он имел значение, неважно. Это подобно тому, что в какой-то губернии учитель ударил ученика указкой - в газетах сообщили, что просвещение делает гигантские успехи. «Так-то пишется российская история!», - заключал Колошин (Колошин, 1862а: 94). Он не хотел такой истории для будущего поколения, поэтому часто сам участвовал в событиях или наблюдал со стороны. Вот почему он не сидел в кабинете, а постоянно путешествовал и общался с людьми. Он хотел давать правдивые факты, а главное, объяснять их.

В следующем номере журнала он сообщал об открытии московскоколоменского участка саратовской железной дороги и предсказывал, что пользу этой дороги скоро можно почувствовать на хлебе, дровах, сене. А что было бы, если бы протянули дорогу в сердце чернозема - об этом даже мечтать слишком смело. Но были уже недовольства новой дорогой, дельцы жаловались, что из Коломны в Москву нельзя вернуться в тот же день. Но это не дорога виновата, уверен Колошин, у наших православных купцов скорых сделок нет: то подпоясаться, то чаю несколько раз попить, то посидеть помолчать; время все еще не ценность в России и скорость и выгоду нескоро еще втиснешь в русскую голову. Такими интересными рассказами Колошин привлекал внимание читателей, просвещал их; не договаривая фраз, он заставлял их задумываться.

Колошин уделял большое внимание крестьянам, живо интересовался их жизнью и проблемами. Он очень удивился высоким ценам на рынке в Троице.Причину ему объяснил «сын природы» (так Колошин называл деревенских людей. - aвm.): настала воля, поэтому стали работать «поменьше да поплоше». Но Колошин считал, что это временное явление. «Несомненно, - писал он, - в ожидании будущих благ, которые должен доставить вольный труд, он нанес последнее время чувствительный ущерб народной производительности, в сложности взятой - зло, конечно, неизбежное на пути к добру, т. е. к более сознательному положению» (Колошин, 1862е: 420). 
О том, что уровень сознательности и духовный мир крестьян еще плохо развит, Колошин ярко показал в своем рассказе «Моя воздушная прогулка». В 1862 г. в Москву приехал французский конструктор Луи Годар, он изобрел шар, на котором за определенную плату катал всех желающих. Колошин, конечно же, не мог упустить такой шанс: увидеть Москву сверху. Он взял с собой подзорную трубу и полетел вместе с Годаром. Он писал, что страшно не было, летели не очень высоко, и, наконец, приземлились в селе Грайвороново. Сбежалось посмотреть, кажется, все село, многие стали помогать складывать шар. Колошин заметил, что у него пропали две бутылки вина, он понял: местные стянули. Потом его тут же заставили заплатить за помятую траву, которая, как заметил он, даже не была скошена. Староста также утверждал, что народ, пока бежал к шару, помял много огурцов - тоже убытки. А потом откровенно стали просить денег на водку. Колошин удивлялся, почему они не просили денег за свой труд - они помогли ему сложить шар. «Этой мысли не было ни в одной душе», - думал он (Колошин, 1862с: 183). Требование заплатить за труд было бы гораздо убедительней и разумней, но почему-то попрошайничать им легче, чем ценить свой труд. Вероятно, это были издержки крепостного права, в душе крестьяне еще оставались крепостными. Но дальше, к ужасу Колошина, они обступили его и стали выпрашивать бутерброды, которые он достал и хотел съесть. «Отдал православным свои бутерброды, - писал он, - драка была хуже, чем между собаками» (там же: 183). Когда все разошлись, один прибежал и принес якорь от воздушного шара, который кто-то успел спрятать в кустах, потом пришел другой и стал спорить, что это он якорь нашел, в итоге они оба стали просить на водку.

Колошин признавался: «Я знал, что в Москве много людей не умных, но чтобы было их столько, сколько обнаружила их мне моя воздушная прогулка, я никогда не смел допустить до нее. Многие до сих пор поздравляют меня точно с возвращением с того света» (там же: 183-184). Он написал около названия рассказа: «Посвящается Гомерам всероссийской религиозности!» Видно, что он с насмешкой употреблял слово «православные», имея в виду славянофильские идеи И. С. Аксакова, в очередной раз показывал, что русский народ надо изучать не в кабинете, а тесно с ним общаясь. Славянофилы идеализировали образ крестьянина, приписали ему православное мировоззрение. Побывав в Троице в большой праздник Сергиев день, Колошин писал, что народу было мало, но напишут, что много, потому что мифы о крестьянах написали славянофилы, и их кабинетные теории надо как-то поддерживать. Но без просвещения и образованности, уверен Колошин, крестьянам не обойтись. Только так они смогут стать равноправными членами общества.

В рассказе об этой прогулке Колошин еще хотел написать о Луи Годаре, 
но, по его словам, это очень скромный человек и поэтому не хотел, чтобы о нем писали, хотя в то время это был известный воздухоплаватель, он получил признание в мире благодаря своему изобретению воздушного шара. А вот в биографии Колошина это знакомство было отмечено. Предполагали, что Колошину удалось бесплатно покататься на шаре. В журнале «Развлечение» была картинка Колошина с Годаром на шаре и подписано: «Колошин даром летал с Годаром» (РГАЛИ. Ф. 191. Оп.1. Д. 3385. Л. 50-51). В любом случае, было это бесплатно или нет, польза от этой прогулки очевидна: Колошин увидел сам и привлек внимание читателей к жизни крестьян после отмены крепостного права.

Колошин любил путешествовать, называл себя странствующим наблюдателем. Он видел жизнь России такой, какая она есть, а не написанную в книгах. Замечал как достоинства, так и недостатки, и обо всем этом писал в журнале. В Нижнем Новгороде, писал он, на улице много грязи, а извозчик сказал, что это хорошо, а то была бы пыль, а пыль вредила здоровью. Грязь, по мнению Колошина, отбивала всякую охоту гулять. В России от торговли шли миллионы, а дороги никто не улучшал. Но грязные улицы не останавливали Колошина от прогулок, он весь день проводил на улице в поисках новостей о городе.

Рассказывал Колошин о хороших нововведениях в российских губерниях. Он узнал, что в Новгород приезжал генерал В. Ф. Лауниц, который объявил полиции: кто возьмет взятки у купцов, будет немилосердно наказан, а кто будет честен, получит вознаграждение деньгами. Колошин приветствовал такое распоряжение, и желал всем городам таких распорядителей. Он побывал в городе Троицкое-Раменское, посетил школу купца-фабриканта Милютина, где учились только работавшие на фабрике, причем учились они бесплатно. Колошин сидел на уроках и наблюдал, как занимались дети крестьян. Он замечал, что дети веселы и здоровы, одеты опрятно, они не пугались, когда вошел в класс барин, а их учителем был крестьянин. Хозяйка Троицко-Раменского была умна, начитана, писал Колошин, современная, добрая женщина. Он желал бы русскому обществу такую барыню, которая занималась детьми и семьей, хотя могла бы блистать в высшем свете.

Колошин закончил свой рассказ о путешествии так: «Вот и вся моя реляция. Каждый выведет из нее, что ему нужно и что он хочет: это уже не мое дело. Во всяком случае, кто до прочтения ее не верил в глубину той истины, что путешествуя, просвещаешься, тот отныне, я надеюсь, устыдится своего скептицизма» (Колошин, 1862d: 277). В том, что путешествия помогали понять жизнь и общество, Колошин не сомневался. Он писал, что жизнь России - это как живой организм, это переход из детства в отрочество, а в отрочестве «жизненные приливы и отливы совершают- 
ся неправильно, явления отступают, так сказать, от размеренного хода. Иначе не может происходить и в организме народном, и общественном» (Колошин, 1862а: 575). Колошин не сомневался, что только с помощью активности всего общества можно изменить плохое положение в лучшую сторону. Свою деятельность для пользы общества он видел в том, чтобы на страницах журнала раскрывать все явления общественной жизни «в видах врачевания тех недугов, которыми страдает каждое общество. Чем полнее будет это раскрытие, тем легче найдутся средства против уклонений обществен-ного организма от желаемого состояния, тем деятельнее этот организм может быть направлен по пути совершенствования» (Колошин, 1862b: 715). Надо писать обо всем, чтобы устранять беззаконие, надо дать свободу народной мысли, дать свободу печати «с теми же ограничениями и гарантиями, как в благоустроенном обществе существует для человека свобода действий» (там же: 716).

С. П. Колошин желал быть реальным просветителем общества, направлять мысли людей на обустройство своей жизни, заставить думать, действовать, доказать, что все перемены в обществе должны происходить при участии самого общества, начиная с постановки и обсуждения проблемы и заканчивая ее исполнением в жизнь. Он хотел быть доступным читателю для понимания собственных мыслей, и в то же время не упрощать проблемы до крайностей, избегать упрощения в серьезных и важных вопросах. Неслучайно, что в июле 1863 г. колошинский журнал получил новое название - он стал называться «Журнал общественный, политический и литературный».

\section{СПИСОК ЛИТЕРАТУРЫ}

Бойко Н. А. (2014) Трансформация общественной и издательской деятельности С. П. Колошина в 1863 г.: польский вопрос [Электронный ресурс] // Информационный гуманитарный портал «Знание. Понимание. Умение». 2014. № 6 (ноябрь - декабрь). URL: http://www.zpu-journal.ru/ e-zpu/2014/6/Boyko_Koloshin-Polish-Question/ [архивировано в Website] (дата обращения: 22.12.2014).

Васильев, Ю. А. (2006) «Кризис истории»- кризис понимания истории // Знание. Понимание. Умение. № 1. С. 35-40.

Васильев, Ю. А. (2009а) О методологических основаниях русской исторической школы: историософские аспекты. Часть I // Знание. Понимание. Умение. № 1. С. 49-58.

Васильев, Ю. А. (2009b) О методологических основаниях русской исторической школы: историософские аспекты. Часть II // Знание. Понимание. Умение. № 2. С. 78-88. 
Васильев, Ю. А. (2011) Идентичность русского народа в историче-ской концепции В. О. Ключевского // Власть. № 7. С. 35-39.

Жукова, Л. Н., Жукова, О. Г. (2014) Русское купечество. Гении дела и творцы истории. М. : Вече. 272 с.

Колошин, С. П. (1861a) Московско-саратовская железная дорога // Зритель общественной жизни, литературы и спорта. № 6.

Колошин, С. П. (1861b) От редакции // Зритель общественной жизни, литературы и спорта». №1.

Колошин, С. П. (1862а) Жизнь в Москве // Зритель общественной жизни, литературы и спорта. № 30.

Колошин, С. П. (1862b) К вопросу о свободе печати // Зритель общественной жизни, литературы и спорта. №22.

Колошин, С. П. (1862c) Моя воздушная прогулка // Зритель общественной жизни, литературы и спорта. № 33.

Колошин, С. П. (1862d) Набег на нижегородскую ярмарку // Зритель общественной жизни, литературы и спорта. № 36.

Колошин, С. П. (1862е) Сутки у Троицы // Зритель общественной жизни, литературы и спорта. № 41.

Туманов, О. Н. (2010) Путешествия русских писателей и публицистов в конце XIX и начале XX вв. в Западную Европу (в период российских реформ). М. : ЦМИК. 236 с.

Бойко Надежда Анатольевна - аспирант кафедры истории Московского гуманитарного университета. Адрес: 111395, Россия, г. Москва, ул. Юности, д. 5, корп. 3. Тел.: +7 (499) 374-55-81. Эл. адрес: historymosgy@ mail.ru. Научный руководитель - д-р историч. наук, проф. Ю. А. Васильев.

Boyko Nadezhda Anatolievna, Postgraduate student, Department of history, Moscow University for the Humanities. Postal address: Bldg. 3, 5 Yunosti St., 111395 Moscow, Russian Federation. Tel.: +7 (499) 374-55-81. E-mail: historymosgy@mail.ru. Research adviser - Yu.A. Vasiliev, Doctor of History, Professor. 